\title{
ROLE OF INFORMATION AND COMMUNICATION TECHNOLOGY ON FARM MANAGEMENT PRACTICES- A CASE STUDY OF THIRUVANANTHAPURAM DISTRICT
}

\author{
${ }^{1}$ Dr. Anilkumar P., ${ }^{2}$ Mr. Aravind R. \\ ${ }^{1}$ Assistant Professor, University College, Thiruvananthapuram \\ ${ }^{2}$ Assistant Professor, Government College, Kottayam
}

DOI: 10.46609/IJSSER.2020.v05i07.011 URL: https://doi.org/10.46609/IJSSER.2020.v05i07.011

\begin{abstract}
Information and Communication Technology (ICT) is a fast-moving technology that dramatically changes the farmer's farm management practices. There are certain accelerating factors like digital literacy, possession of information and communication technology media, awareness, and use of information regarding the farm practices which had an impact on the extent of use and satisfaction of various information and communication media. Farmers' perception of the usefulness of the information provided by various ICT media is positively related to the status of the impact accelerating factors. The extent of usefulness score is highest for Low skill required media; print media, mass media, and extension services to access information as compared to High skill required media: mobile internet and Agri. portal to access information media. The information communication technology media in which the print, extension, and mobile media played a key role in disseminating information on the promotion of various dimensions of farm management practices of the farming community on the one hand and also widens asymmetry in the perception on use among respondents. The expansion of these media can achieve increasing the reach of the usefulness of information among the farming community along with the reduction of information asymmetry among them.
\end{abstract}

Keywords: ICT, farm management, HSR media, LSR media

\section{INTRODUCTION}

Knowledge is the critical factor which differentiates the status of an individual in a community from others. The content, the application, and speed of the use of the acquired knowledge greatly depend on the technology and media through which the relevant information is provided. The application of modern information and communication technology (ICT) in the information 


\section{International Journal of Social Science and Economic Research}

ISSN: $2455-8834$

Volume: 05, Issue: 07 "July 2020"

dissemination process revolutionized the speed, efficiency, content, and application of knowledge generation mechanism which transforms the farm practices of the farmers. Information and Communication Technology (ICT) comprises a range of elements viz., computer hardware and software, television, radio, mobile phones, personal computers, kiosks, and the policies that govern these media and devices [1]. It provides new approaches and areas for communicating and sharing the information [2], thus reducing the distance among different communities. Apart from these, ICT plays an effective role in agriculture development especially in the decision-making aspect of the livelihood assets of farming communities in rural areas [3]. Significant changes in the rural community through Information and Communication Technology [4] resulted in increased production, information, and knowledge [5,6]. Information sharing on new production processes with farmers was prominent in the sixties which was the key to the success of the Green revolution [7]. Rural economies can be benefitted from ICT by focusing on production, consumption, and social services in rural areas [8]. However, Sen argued persuasively that the development is not just about macroeconomic growth, but an increase in the overall number and quality of choices available to the individuals in pursuing the farmers' lives and livelihoods [9]. The study analyses the usefulness and satisfaction of information and communication technology media in farm management practices.

\section{DATA SOURCES AND METHODOLOGY}

The district Thiruvananthapuram, the capital city of Kerala has been selected for the study. For sample purposes, one block from each geographical terrain is selected randomly. The randomly selected Blocks are Chirayinkeezhu, Parassala, and Vamanapuram, representing low land, midland, and high land regions respectively. The total numbers of cultivators (Census, 2011) are 5966, 2559, and 2229 respectively for Vamanapuram, Parassala, and Chirayinkeezhu Blocks. The sample size from selected Blocks is decided based on precision rule and confidence interval [10], the respondents being 49, 109 and 42 respectively from the blocks

\section{Concepts}

For the present study, information and communication technology media which provide information about agricultural practices to farmers are divided into print media, mass media, extension services, mobile, internet and agri. portal. These ICT media are combined into less skill required (LSR) to access information media and high skill required (HSR) to access information media. The LSR media includes the print, mass media and extension services while HSR media consists of mobile, internet and agri. portals.

\section{Analysis and results}




\section{International Journal of Social Science and Economic Research}

ISSN: $2455-8834$

Volume: 05, Issue: 07 "July 2020"

Farm management is the decision involved in the cultivation practices which operating a farm for maximum output. Information and communication technology media plays a very important role in the decision-making process in farm management. In this context, farm management activities include sowing, fertilizer, pesticides, weeds, and irrigation were taken for the study for the impact of Information and communication technology.

\section{Usefulness of ICT in Farm Management}

Data on the effect of information through media on the farm management practices followed during paddy cultivation is measured in terms of a five-point scale Likert Scale (Table1). It is found that out of the five farm practices, information through extension services was useful for maximum respondents in fertilizer $(62.00 \%)$, pesticides $(57.50 \%)$ followed by the print media where maximum farmers got useful information about pesticides $(56.50 \%)$ and fertilizer $(55.00$ $\%)$. Mobile was also much useful for the farmers in getting information about fertilizer (46.00 $\%$ ) and pesticides $(44.00 \%)$. In the case of mass media, maximum respondents $(43.00 \%)$ got useful information about pesticides, while the information with regard to the fertilizer was useful to 42.50 percent of the farmers. Both the Agri portal and the internet were useful to the farmers in getting information about the farm practices to the range of 13.00 to 34.50 percent. Among the five farm practices, farmers do not depend much on the media for the information to know about the irrigation practices when compared to that of the fertilizer and pesticides. Information about seed sowing $(40.00 \%)$ and weed management $(35.00 \%)$ is provided mainly through extension services.

Table 1: Farm Management Practices by ICT Media

\begin{tabular}{|c|c|c|c|c|c|c|}
\hline \multirow[b]{2}{*}{$\begin{array}{c}\text { ICT } \\
\text { Media }\end{array}$} & \multirow[b]{2}{*}{ Scale } & \multicolumn{5}{|c|}{ Farm Management Practices } \\
\hline & & $\begin{array}{c}\text { Sowing } \\
(\%)\end{array}$ & $\begin{array}{c}\text { Fertilize } \\
\text { r }(\%)\end{array}$ & $\begin{array}{c}\text { Pesticide } \\
\text { s (\%) }\end{array}$ & $\begin{array}{c}\text { Weeds } \\
(\%)\end{array}$ & $\begin{array}{c}\text { Irrigati } \\
\text { on } \\
\%(\%)\end{array}$ \\
\hline \multirow{6}{*}{ 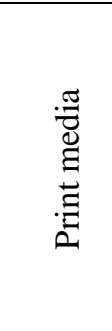 } & $\begin{array}{c}\text { Not at all } \\
\text { useful }\end{array}$ & 12.50 & 10.50 & 9.00 & 14.00 & 14.50 \\
\hline & Not useful & 44.00 & 29.00 & 28.50 & 46.00 & 49.00 \\
\hline & Neutral & 7.50 & 3.00 & 4.00 & 7.00 & 11.00 \\
\hline & Useful & 35.00 & 55.00 & 56.50 & 32.00 & 24.50 \\
\hline & very useful & 1.00 & 2.50 & 2.00 & 1.00 & 1.00 \\
\hline & Total & 100.00 & 100.00 & 100.00 & 100.00 & 100.00 \\
\hline \multirow{5}{*}{ 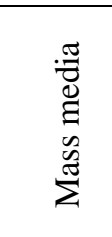 } & not at all useful & 14.50 & 11.00 & 10.50 & 12.00 & 13.50 \\
\hline & Not useful & 51.00 & 40.00 & 39.00 & 51.00 & 53.50 \\
\hline & Neutral & 7.50 & 5.00 & 7.00 & 9.50 & 12.00 \\
\hline & Useful & 25.50 & 42.50 & 43.00 & 27.00 & 20.00 \\
\hline & very useful & 1.50 & 1.50 & .50 & .50 & 1.00 \\
\hline
\end{tabular}


International Journal of Social Science and Economic Research

ISSN: 2455-8834

Volume: 05, Issue: 07 "July 2020"

\begin{tabular}{|c|c|c|c|c|c|c|}
\hline & Total & 100.00 & 100.00 & 100.00 & 100.00 & 100.00 \\
\hline \multirow{6}{*}{$\begin{array}{l}\frac{0}{0} \\
\frac{0}{0} \\
\stackrel{0}{x} \\
0\end{array}$} & not at all useful & 9.50 & 6.50 & 8.00 & 9.50 & 13.50 \\
\hline & Not useful & 40.00 & 23.50 & 29.50 & 45.00 & 49.50 \\
\hline & Neutral & 10.00 & 7.00 & 4.50 & 10.00 & 8.50 \\
\hline & Useful & 40.00 & 62.00 & 57.50 & 35.00 & 28.00 \\
\hline & very useful & .50 & 1.0 & .50 & .50 & 0.50 \\
\hline & Total & 100.00 & 100.0 & 100.00 & 100.00 & 100.00 \\
\hline \multirow{6}{*}{$\begin{array}{l}\frac{0}{\pi 0} \\
\frac{0}{2}\end{array}$} & $\begin{array}{c}\text { Not at all } \\
\text { useful }\end{array}$ & 9.00 & 8.50 & 10.00 & 11.00 & 11.00 \\
\hline & Not useful & 44.50 & 35.50 & 37.00 & 48.00 & 50.50 \\
\hline & Neutral & 8.00 & 8.50 & 8.00 & 14.50 & 16.50 \\
\hline & Useful & 38.00 & 46.00 & 44.00 & 26.50 & 22.00 \\
\hline & very useful & .50 & 1.50 & 1.00 & 00 & 0.00 \\
\hline & Total & 100.00 & 100.00 & 100.00 & 100.00 & 100.00 \\
\hline \multirow{6}{*}{ 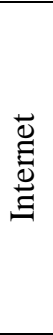 } & $\begin{array}{c}\text { Not at all } \\
\text { useful }\end{array}$ & 12.00 & 12.50 & 13.00 & 14.50 & 14.50 \\
\hline & Not useful & 51.00 & 41.00 & 43.50 & 56.00 & 56.50 \\
\hline & Neutral & 16.00 & 11.50 & 11.50 & 14.00 & 15.50 \\
\hline & Useful & 20.50 & 34.50 & 32.00 & 15.50 & 13.00 \\
\hline & very useful & .50 & 0.50 & 00 & 00 & 0.50 \\
\hline & Total & 100.00 & 100.00 & 100.00 & 100.00 & 100.00 \\
\hline \multirow{6}{*}{ 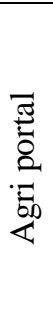 } & $\begin{array}{c}\text { Not at all } \\
\text { useful }\end{array}$ & 12.00 & 12.00 & 11.50 & 13.50 & 12.00 \\
\hline & Not useful & 55.50 & 40.50 & 40.00 & 53.00 & 56.00 \\
\hline & Neutral & 18.00 & 14.50 & 14.00 & 18.50 & 18.50 \\
\hline & Useful & 14.00 & 32.00 & 33.50 & 14.50 & 13.50 \\
\hline & very useful & .50 & 1.00 & 1.00 & .50 & 0.00 \\
\hline & Total & 100.00 & 100.00 & 100.00 & 100.00 & 100.00 \\
\hline
\end{tabular}

Source: Primary Survey

\section{Farm Management and Socio-economic condition}

Data analysis on the age-wise/education wise/landholding wise classification of the respondents with the extent of use of the information through different media about the different farm management practices (sowing, fertilizer, pesticides, weeds, irrigation) during paddy cultivation is depicted in Table 2. The extent of the use of different media for farm management practices is represented by a usefulness score. The methodology of calculation of this score is already explained in the section above 
International Journal of Social Science and Economic Research

ISSN: $2455-8834$

Volume: 05, Issue: 07 "July 2020"

Table 2: ICT media for Farm management Practices by the Socio- economic Condition

\begin{tabular}{|c|c|c|c|c|c|c|c|}
\hline \multirow[b]{2}{*}{$\begin{array}{l}\text { Cate } \\
\text { gory }\end{array}$} & \multirow[b]{2}{*}{$\begin{array}{l}\text { Distribution of } \\
\text { Category }\end{array}$} & \multicolumn{5}{|c|}{ Farm Management Practices } & \multirow{2}{*}{$\begin{array}{c}\text { Aggregate } \\
\text { extent of use } \\
\text { Score Farm } \\
\text { Practice }\end{array}$} \\
\hline & & $\begin{array}{c}\text { Sowing } \\
\text { extent of } \\
\text { use Score }\end{array}$ & $\begin{array}{l}\text { Fertilizer } \\
\text { extent of } \\
\text { use score }\end{array}$ & $\begin{array}{l}\text { Pesticides } \\
\text { extent of } \\
\text { use Score }\end{array}$ & $\begin{array}{c}\text { Weeds } \\
\text { extent of } \\
\text { use Score }\end{array}$ & $\begin{array}{c}\text { Irrigation } \\
\text { extent of } \\
\text { use Score }\end{array}$ & \\
\hline \multirow{6}{*}{$\stackrel{8}{\&}$} & Up to 45 years & 18.41 & 21.03 & 20.58 & 17.83 & 17.03 & 94.83 \\
\hline & $46-55$ years & 17.16 & 19.97 & 19.71 & 16.61 & 15.79 & 89.24 \\
\hline & $56-65$ years & 15.19 & 16.96 & 16.85 & 14.77 & 14.27 & 78.04 \\
\hline & above 65 years & 11.20 & 11.7 & 11.60 & 10.71 & 10.83 & 56.06 \\
\hline & Average & 15.57 & 17.57 & 17.35 & 15.08 & 14.54 & 80.10 \\
\hline & Test statistics & $\begin{array}{c}\mathrm{F}=20.886 \\
\mathrm{df}=3 \text { and } \\
196 \\
\mathrm{Sig}=0.000\end{array}$ & $\begin{array}{c}\mathrm{F}=35.136 \\
\mathrm{df}=3 \text { and } \\
196 \\
\mathrm{Sig}=0.000\end{array}$ & $\begin{array}{c}\mathrm{F}=32.991, \\
\mathrm{df}=3 \text { and } \\
196 \\
\mathrm{Sig}=0.000\end{array}$ & $\begin{array}{c}\mathrm{F}=21.201, \\
\mathrm{df}=3 \text { and } \\
196 \\
\mathrm{Sig}=0.000\end{array}$ & 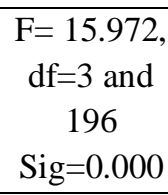 & $\begin{array}{c}\mathrm{F}=30.468 \\
\mathrm{df}=3 \text { and } 196 \\
\mathrm{Sig}=0.000\end{array}$ \\
\hline \multirow{9}{*}{ 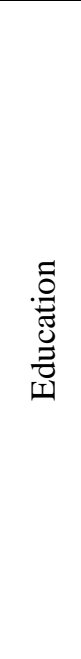 } & Read and Write & 10.07 & 10.20 & 9.87 & 9.73 & 9.73 & 49.60 \\
\hline & Primary Level & 12.38 & 13.19 & 12.92 & 11.92 & 11.96 & 62.38 \\
\hline & Upper Primary & 12.87 & 13.87 & 14.00 & 12.74 & 12.22 & 65.70 \\
\hline & High School & 16.14 & 18.10 & 17.94 & 15.68 & 15.00 & 82.86 \\
\hline & $\begin{array}{c}\text { Higher } \\
\text { Secondary }\end{array}$ & 15.92 & 19.80 & 19.36 & 14.60 & 13.72 & 83.40 \\
\hline & Degree/Diploma & 18.59 & 21.75 & 21.60 & 18.34 & 17.25 & 97.53 \\
\hline & $\begin{array}{l}\text { Professional } \\
\text { Degree / PG }\end{array}$ & 20.94 & 22.94 & 22.44 & 20.38 & 20.63 & 107.31 \\
\hline & Average & 15.57 & 17.57 & 17.35 & 15.08 & 14.5400 & 80.10 \\
\hline & Test statistics & 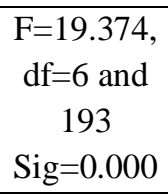 & 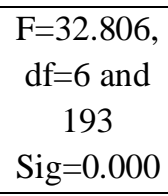 & 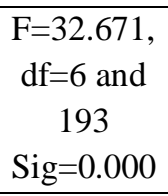 & $\begin{array}{c}\mathrm{F}=20.131, \\
\mathrm{df}=6 \text { and } \\
193 \\
\mathrm{Sig}=0.000\end{array}$ & 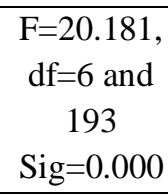 & $\begin{array}{c}\mathrm{F}=30.756 \\
\mathrm{df}=6 \text { and } 193 \\
\mathrm{Sig}=0.000\end{array}$ \\
\hline \multirow{6}{*}{ 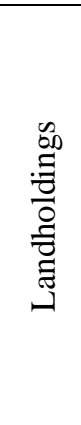 } & Below 100 & 12.18 & 13.67 & 13.65 & 12.00 & 11.79 & 63.30 \\
\hline & 100 and 160 & 16.10 & 17.93 & 17.88 & 15.79 & 15.04 & 82.75 \\
\hline & 160 and 240 & 15.80 & 18.51 & 18.10 & 15.68 & 14.68 & 82.78 \\
\hline & Above 240 & 17.65 & 19.73 & 19.27 & 16.29 & 16.17 & 89.10 \\
\hline & Average & 15.57 & 17.57 & 17.35 & 15.08 & 14.54 & 80.10 \\
\hline & Test statistics & $\begin{array}{c}\mathrm{F}=12.720 \\
\mathrm{df}=6 \text { and } \\
193 \\
\mathrm{Sig}=0.000\end{array}$ & $\begin{array}{c}\mathrm{F}=13.075 \\
\mathrm{df}=6 \text { and } \\
193 \\
\mathrm{Sig}=0.000\end{array}$ & $\begin{array}{c}\mathrm{F}=11.490 \\
\mathrm{df}=6 \text { and } \\
193 \\
\mathrm{Sig}=0.000\end{array}$ & $\begin{array}{c}\mathrm{F}=9.293 \\
\mathrm{df}=6 \text { and } \\
193 \\
\mathrm{Sig}=0.000\end{array}$ & $\begin{array}{c}\mathrm{F} 8.972, \\
\mathrm{df}=6 \text { and } \\
193 \\
\mathrm{Sig}=0.000\end{array}$ & $\begin{array}{c}\mathrm{F}=13.083 \\
\mathrm{df}=6 \text { and } 193 \\
\mathrm{Sig}=0.000\end{array}$ \\
\hline \multirow{5}{*}{$\frac{\frac{u}{0}}{\frac{0}{n}}$} & parassala & 16.08 & 19.24 & 19.27 & 16.65 & 15.24 & 86.49 \\
\hline & vamanapuram & 15.24 & 16.95 & 16.63 & 14.31 & 14.06 & 77.18 \\
\hline & chirayinkeezhu & 15.8333 & 17.21 & 16.98 & 15.21 & 14.98 & 80.21 \\
\hline & Average & 15.5700 & 17.57 & 17.35 & 15.08 & 14.54 & 80.10 \\
\hline & Test statistics & $\begin{array}{l}F=0.621, \\
d f=2 \text { and }\end{array}$ & $\begin{array}{l}F=3.419 \\
d f=2 \text { and }\end{array}$ & $\begin{array}{c}F=0.4 .615 \\
d f=2 \text { and }\end{array}$ & $\begin{array}{l}F=.4 .527 \\
d f=2 \text { and }\end{array}$ & $\begin{array}{l}\mathrm{F}=1.489, \\
\mathrm{df}=2 \text { and }\end{array}$ & $\begin{array}{c}\mathrm{F}=2.951 . \mathrm{df}=2 \\
\text { and } 197\end{array}$ \\
\hline
\end{tabular}




\section{International Journal of Social Science and Economic Research}

ISSN: $2455-8834$

Volume: 05, Issue: 07 "July 2020"

\begin{tabular}{|c|c|c|c|c|c|c|c|}
\hline & $\begin{array}{c}197 \\
\text { Sig=0.538 }\end{array}$ & 197 & 197 & 197 & 197 & \multirow{2}{*}{ Sig=0.538 } \\
& & & Sig=0.035 & Sig=0..011 & Sig=0.012 & Sig=0..228 & \\
\hline
\end{tabular}

Source: Primary Survey

The extent of use of various ICT media for farm management practices by farmers is greatly influenced by their age, education, and landholding size.

The usefulness of these media for various farm management practices is lower for the higher age group as compared to the lower age group. The lower age group finds more useful in farm management information provided by these media. The value of chi-square statistics shows a significant difference in the usefulness status of the information provided by these media among the various age groups.

At the same time, farm management practices have a positive relationship with education level and landholding size. As the education level improves, the farmer's response to the usefulness of the information provided for farm management increases. Similar is the case with landholding size. As the farm holding size increases, the farmers' perception of the usefulness of the information provided by ICT media also increases. The difference in perception of various education and landholding groups on the usefulness of information (as represented by the usefulness score) are statistically significant, as evident from the values given in the Table.

Among the selected Blocks, the positive response on the usefulness of farm management information provided by various ICT media is greater in Parassala Block compared to others. The usefulness score of all dimensions of farm management practices is higher for Parassala Block. However, these differences in usefulness score of information by ICT media between selected Blocks are not very significant as shown by the value of chi-square statistics in the Table.

\section{Satisfaction of ICT Media in Farm Management}

Similar to land preparation, an aggregate satisfaction score of information provided by various ICT media for farm management practices is estimated. Table 3 shows the satisfaction score on information provided by various ICT media for farm management practices. Within various ICT media, the satisfaction level of information from extension services is highest followed by print and mass media. The satisfaction level of information from the Agri portal and internet are the least. The age, education, and landholding size influence the level of satisfaction of information for farm management practices by farmers. Concerning age, there is a negative association between age and satisfaction of information. It implies that the satisfaction level of farm management information is lower for the higher age group as compared to the lower age group. 


\section{International Journal of Social Science and Economic Research}

ISSN: 2455-8834

Volume: 05, Issue: 07 "July 2020"

The factors of education and landholding size have a positive association with the satisfaction level of farm management information. The level of satisfaction on information provided by ICT media is greater for higher education groups and higher landholding groups. The difference in the satisfaction level of farm management information between age, education, and landholding groups is statistically significant as shown in the Table 3. Within the selected Blocks, the aggregate level of satisfaction is highest in Parassala Block. However, the status of the satisfaction score of all Blocks is not homogenous across various ICT media. The satisfaction level of information from mass media, extension services, and mobile are highest for Parassala Block. The satisfaction from print media, internet, and the Agri portal are highest for ChirayinkeezhuBlock. However, these differences in satisfaction on information provided by various ICT Media between the selected Blocks are not statistically significant..

Table 3: Satisfaction of and ICT Media in Farm Management Practices by Socio-economic Conditions

\begin{tabular}{|c|c|c|c|c|c|c|c|c|}
\hline \multirow{3}{*}{$\begin{array}{l}\text { Cate } \\
\text { gory }\end{array}$} & \multirow{3}{*}{$\begin{array}{l}\text { Distribution of } \\
\text { category }\end{array}$} & \multicolumn{6}{|c|}{ ICT media } & \multirow{3}{*}{$\begin{array}{c}\text { Aggregate } \\
\text { Satisfactio } \\
\text { n score }\end{array}$} \\
\hline & & \multicolumn{3}{|c|}{ LSR Media } & \multicolumn{3}{|c|}{ HSR Media } & \\
\hline & & $\begin{array}{l}\text { Print } \\
\text { Media }\end{array}$ & $\begin{array}{c}\text { Mass } \\
\text { Media }\end{array}$ & Extension & Mobile & Internet & $\begin{array}{l}\text { Agri. } \\
\text { Portal }\end{array}$ & \\
\hline \multirow{6}{*}{$\stackrel{80}{<}$} & Below 45 years & 3.49 & 3.28 & 3.34 & 3.21 & 3.10 & 3.14 & 19.52 \\
\hline & $46-55$ years & 3.24 & 3.23 & 3.32 & 3.02 & 2.82 & 2.71 & 18.34 \\
\hline & 56-65 years & 2.74 & 2.72 & 2.85 & 2.70 & 2.43 & 2.49 & 15.85 \\
\hline & above 65 years & 2.09 & 1.83 & 2.14 & 1.89 & 1.77 & 1.77 & 11.43 \\
\hline & Average & 2.89 & 2.80 & 2.94 & 2.72 & 2.54 & 2.53 & 16.38 \\
\hline & Test statistics & $\begin{array}{c}\mathrm{F}=13.552 \\
\mathrm{df}=3 \text { and } \\
196 \\
\mathrm{Sig}=0.000\end{array}$ & $\begin{array}{c}\mathrm{F}=18.562 \\
\mathrm{df}=3 \mathrm{and} \\
196 \\
\mathrm{Sig}=0.000\end{array}$ & $\begin{array}{c}\mathrm{F}=13.114 \\
\mathrm{df}=3 \text { and } \\
196 \\
\mathrm{Sig}=0.000\end{array}$ & $\begin{array}{c}\mathrm{F}=15.059 \\
\mathrm{df}=3 \mathrm{and} \\
196 \\
\mathrm{Sig}=0.000\end{array}$ & $\begin{array}{c}\mathrm{F}=14.748 \\
\mathrm{df}=3 \mathrm{and} \\
196 \\
\mathrm{Sig}=0.000\end{array}$ & $\begin{array}{c}\mathrm{F}=14.676 \\
\mathrm{df}=3 \text { and } \\
196 \\
\mathrm{Sig}=0.000\end{array}$ & $\begin{array}{c}\mathrm{F}=22.461, \\
\mathrm{df}=3 \text { and } \\
196 \\
\mathrm{Sig}=0.000\end{array}$ \\
\hline \multirow{9}{*}{ 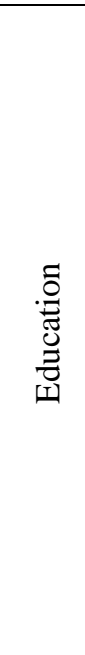 } & Read and Write & 1.60 & 1.60 & 1.53 & 1.60 & 1.60 & 1.60 & 9.53 \\
\hline & Primary Level & 2.23 & 2.04 & 2.62 & 2.00 & 1.96 & 2.08 & 12.92 \\
\hline & Upper Primary & 2.39 & 2.39 & 2.43 & 2.30 & 2.04 & 2.13 & 13.70 \\
\hline & High School & 2.86 & 2.79 & 3.00 & 2.67 & 2.50 & 2.46 & 16.29 \\
\hline & $\begin{array}{c}\text { Higher } \\
\text { Secondary }\end{array}$ & 3.24 & 3.24 & 3.25 & 3.12 & 2.88 & 2.52 & 18.04 \\
\hline & $\begin{array}{c}\text { Degree/Diplom } \\
\text { a }\end{array}$ & 3.59 & 3.44 & 3.38 & 3.34 & 3.03 & 3.188 & 19.97 \\
\hline & $\begin{array}{l}\text { Professional } \\
\text { Degree / PG }\end{array}$ & 4.00 & 3.88 & 4.00 & 3.88 & 3.63 & 3.63 & 23.00 \\
\hline & Average & 2.89 & 2.89 & 2.94 & 2.72 & 2.54 & 2.53 & 16.38 \\
\hline & Test statistics & $\begin{array}{c}\mathrm{F}=16.456, \\
\mathrm{df}=6 \text { and } \\
193\end{array}$ & $\begin{array}{c}\mathrm{F}=15.996 \\
\mathrm{df}=6 \text { and } \\
193\end{array}$ & $\begin{array}{c}\mathrm{F}=13.516 \\
\mathrm{df}=6 \text { and } \\
193\end{array}$ & $\begin{array}{c}\mathrm{F}=17.048 \\
\mathrm{df}=6 \text { and } \\
193\end{array}$ & $\begin{array}{c}\mathrm{F}=13.451, \\
\mathrm{df}=6 \text { and } \\
193\end{array}$ & $\begin{array}{c}\mathrm{F}=14.281, \\
\mathrm{df}=6 \text { and } \\
193\end{array}$ & $\begin{array}{c}\mathrm{F}=24.365, \\
\mathrm{df}=6 \text { and } \\
193\end{array}$ \\
\hline
\end{tabular}


International Journal of Social Science and Economic Research

ISSN: $2455-8834$

Volume: 05, Issue: 07 "July 2020"

\begin{tabular}{|c|c|c|c|c|c|c|c|c|}
\hline & & Sig $=0.000$ & Sig $=0.000$ & Sig $=0.000$ & $\mathrm{Sig}=0.000$ & Sig $=0.000$ & Sig $=0.000$ & $\mathrm{Sig}=0.000$ \\
\hline \multirow{6}{*}{ 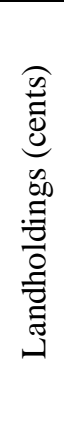 } & Below 100 & 2.26 & 2.12 & 2.40 & 2.21 & 2.05 & 1.88 & 12.91 \\
\hline & 100 and 160 & 2.97 & 2.93 & 3.00 & 2.78 & 2.57 & 2.68 & 16.93 \\
\hline & 160 and 240 & 3.00 & 2.83 & 2.95 & 2.66 & 2.44 & 2.54 & 16.41 \\
\hline & Above 240 & 3.23 & 3.23 & 3.36 & 3.15 & 3.00 & 2.88 & 18.74 \\
\hline & Average & 2.89 & 2.80 & 2.94 & 2.72 & 2.54 & 2.53 & 16.38 \\
\hline & Test statistics & $\begin{array}{c}\mathrm{F}=7.230 \\
\mathrm{df}=3 \text { and } \\
196 \\
\mathrm{Sig}=0.000\end{array}$ & $\begin{array}{c}\mathrm{F}=9.754 \\
\mathrm{df}=3 \text { and } \\
196 \\
\mathrm{Sig}=0.000\end{array}$ & $\begin{array}{c}\mathrm{F}=7.046 \\
\mathrm{df}=3 \text { and } \\
196 \\
\mathrm{Sig}=0.000\end{array}$ & $\begin{array}{c}\mathrm{F}=6.841, \\
\mathrm{df}=3 \text { and } \\
196 \\
\mathrm{Sig}=0.000\end{array}$ & $\begin{array}{c}\mathrm{F}=7.992, \\
\mathrm{df}=3 \text { and } \\
196 \\
\mathrm{Sig}=0.000\end{array}$ & $\begin{array}{c}\mathrm{F}=10.609, \\
\mathrm{df}=3 \text { and } \\
196 \\
\mathrm{Sig}=0.000\end{array}$ & $\begin{array}{c}\begin{aligned} & \mathrm{F}= 11.191, \\
& \mathrm{df}=3 \text { and } \\
& 196 \\
& \mathrm{Sig}\end{aligned}=0.000\end{array}$ \\
\hline \multirow{5}{*}{$\frac{y}{\ddot{\theta}}$} & Parassala & 2.8776 & 2.94 & 3.06 & 2.88 & 2.53 & 2.59 & 16.86 \\
\hline & Vamanapuram & 2.9083 & 2.78 & 2.85 & 2.61 & 2.51 & 2.44 & 16.05 \\
\hline & Chirayinkeezhu & 2.8333 & 2.71 & 3.05 & 2.81 & 2.60 & 2.67 & 16.67 \\
\hline & Average & 2.8850 & 2.81 & 2.94 & 2.72 & 2.54 & 2.53 & 16.38 \\
\hline & Test statistics & $\begin{array}{c}\mathrm{F}=0.072 \\
\mathrm{df}=2 \text { and } \\
197 \\
\mathrm{Sig}=0.931\end{array}$ & $\begin{array}{c}\mathrm{F}=0.553, \\
\mathrm{df}=2 \text { and } \\
197 \\
\mathrm{Sig}=0.553\end{array}$ & $\begin{array}{c}\mathrm{F}=0.925 \\
\mathrm{df}=2 \mathrm{and} \\
197 \\
\mathrm{Sig}=0.398\end{array}$ & $\begin{array}{c}\mathrm{F}=1.286 \\
\mathrm{df}=2 \mathrm{and} \\
197 \\
\mathrm{Sig}=0.276\end{array}$ & $\begin{array}{c}\mathrm{F}=0.103, \\
\mathrm{df}=2 \mathrm{and} \\
197 \\
\mathrm{Sig}=0.902\end{array}$ & $\begin{array}{c}\mathrm{F}=1.019 \\
\mathrm{df}=2 \mathrm{and} \\
197 \\
\mathrm{Sig}=0.398\end{array}$ & $\begin{array}{c}\mathrm{F}=0.498 \\
\mathrm{df}=2 \text { and } \\
197 \\
\mathrm{Sig}=0.608\end{array}$ \\
\hline
\end{tabular}

Source: Primary Survey

\section{Type of ICT Media and Extent of Use and Satisfaction in Farm Management Practices}

Table 4 depicts the extent of use and satisfaction of information between LSR and HSR media. The extent of usefulness score is highest for LSR as compared to HSR media. The mean score of usefulness score of information from LSR and HSR are statistically different and independent. The dependent t-test value for usefulness score of information form LSR and HSR are significant implies that usefulness status from LSR media by the respondent is statistically different from HSR media. The same is true for the level of aggregate satisfaction score on information derived from LSR and HSR media. The satisfaction of information from LSR is greater than HSR media and this difference is also statistically significant.

\section{Table 4: Aggregate Extent of Use and Satisfaction of LSRM and HSRM for Farm Management Practices}

\begin{tabular}{|c|c|c|c|}
\hline Category & Types of media & $\begin{array}{l}\text { Mean } \\
\text { score }\end{array}$ & $\begin{array}{c}\text { Dependent t- } \\
\text { test }\end{array}$ \\
\hline \multirow{2}{*}{$\begin{array}{l}\text { Aggregate } \\
\text { extent of use }\end{array}$} & LSR media & 41.58 & \multirow{2}{*}{$\begin{array}{c}\mathrm{t} \text {-value }=4.88 \\
\mathrm{df}=199 \\
\mathrm{Sig}=0.000\end{array}$} \\
\hline & HSR media & 38.52 & \\
\hline \multirow{2}{*}{$\begin{array}{l}\text { Aggregate } \\
\text { satisfaction }\end{array}$} & LSR media & 8.62 & \multirow{2}{*}{$\begin{array}{c}\mathrm{t} \text {-value }=6.50 \\
\mathrm{df}=199 \\
\text { Sig }=0.000\end{array}$} \\
\hline & HSR media & 7.78 & \\
\hline
\end{tabular}

Source: Primary Survey 
International Journal of Social Science and Economic Research

ISSN: 2455-8834

Volume: 05, Issue: 07 "July 2020"

\section{CONCLUSION}

Among the farm practices, farmers' perception of the usefulness of information is greater for the application of fertilizer and pesticides. Compared to other purposes, irrigation is an item for which farmers find that provided information is least useful. However, in the access of farmers across various socio-economic groups such as education, landholdings showed a positive association of information and communication technology used in farm management practices. The type of media particularly modern information and communication technology media such as internet Agri. portal and mobile showed a less contribution to the farm management practices. The difference in the satisfaction level of information technology in farm management between socio-economic conditions, however, higher education, lower age group, and larger farm size holdings show a positive approach to farm management. The farmers' access to the high skill required media to its fullest potential is still a dream.

\section{REFERENCES}

[1] Warren, M. 2002. Digital divides and the adoption of information and communication technologies in the UK farm sector, International Journal of Information Technology and Management. 1(4):385-405.

[2] Herselman, M. E. 2003. ICT in rural areas in South Africa: various case studies, Informing Science Proceedings, 945-955

[3] Taragola, N. and Van Lierde, D. F. 2010. Internet Behaviour of Horticultural Growers in Flanders, Belgium. Computers and Electronics in Agriculture. 70.10.1016/j.compag.2009.09.004.

[4] Poonam, D, and Singh, D. 2012.Information \& Communication Technology for Integrated Rural Development, Himanshu Publications.210 p.

[5] Arunachalam, S. 1999. Information and Knowledge in the Age of Electronic ommunication: A Developing Country Perspective. Journal of Information Science. 25(6): 465

[6] Yadav, V. S., Sharma, M. T., Halakatti, S. V., Jahagirdar, K. A. and Manjunath, L. 2015. Information Communication Technology for Rural Development. Agri biovet Press, 180 p.

[7] Farmer, B. H. 1986. "Perspectives on the 'Green Revolution' in South Asia". Modern Asian Studies. 20 (01): 175-199. 
International Journal of Social Science and Economic Research

ISSN: 2455-8834

Volume: 05, Issue: 07 "July 2020"

[8] Malhotra, C., Chariar, V. M., Das, L. K. and Ilavarasan, P. V. 2006. ICT for Rural Development: An Inclusive Framework for e-Governance, pp. 216-226

[9] Sen, A. 1999.Development as freedom. Anchor $384 \mathrm{p}$.

[10] www.surveysystem.com/sscalc.htm. 